Tolnurst, J. C. (1958). J. gen. Microbiol. 18, 295-301

\title{
The Effect of the Medium on the Cultivation of Mycobacterium balnei at $37^{\circ}$
}

\author{
By JEAN C. TOLHURST \\ Alfred Hospital, Melbourne, Australia
}

SUMMARY: Mycobacterium balnei grows best at temperatures about $32^{\circ}$. Growth occurs at $37^{\circ}$ only on certain media. The organism is more susceptible at $37^{\circ}$ than at $32^{\circ}$ to the inhibitory effects of oleic acid added to a simple defined medium. This appears to explain the failure of more complex media to support growth at the higher temperature.

Mycobacterium ulcerans, described in 1948 by MacCallum, Tolhurst, Buckle \& Sissons, was peculiar among the mycobacteria in the limited temperature range permitting growth and especially for its failure to grow in primary culture at $37^{\circ}$. This observation led directly to the primary cultivation of $M$. balne $i$ by Nordén $\&$ Linell (1951), since Lowenstein-Jensen medium inoculated with material from human lesions gave growth when incubated at $31^{\circ}$ but not when incubated at $37^{\circ}$ (see also Linell \& Nordén, 1954.)

Subcultivation of Mycobacterium ulcerans on a variety of media has so far failed to give sustained growth at $37^{\circ}$. Subcultivation of $M$. balnei is successful at $37^{\circ}$ under certain conditions. Thus Nordén (personal communication, 1955) using large inocula, obtained growth on Lowenstein-Jensen medium at $37^{\circ}$, and Leach \& Fenner (1954) reported growth at $37^{\circ}$ in Dubos medium containing albumin and Tween 80 . Yet subcultures of this organism, made when it was received here, yielded no growth on egg-yolk agar when incubated at $37^{\circ}$. The possible effect of the nature of the medium on growth at different temperatures was therefore considered.

In preliminary experiments the addition of activated charcoal to blood agar or to nutrient broth permitted growth at $37^{\circ}$. The significance of this finding was investigated.

\section{METHODS}

Liquid media. The basal medium used was that of Proskauer \& Beck (PB) as modified by Youmans (1946) except that the concentration of glycerol was decreased to $1 \%(\mathrm{v} / \mathrm{v})$. This medium contained: asparagine, $5 \cdot 0 \mathrm{~g}$.; $\mathrm{KH}_{2} \mathrm{PO}_{4}$, 5.0 g.; $\mathrm{K}_{2} \mathrm{SO}_{4}, 0.5 \mathrm{~g}$.; $\mathrm{Mg}$ citrate, $1.5 \mathrm{~g}$; glycerol, $10 \mathrm{ml}$; water to $1000 \mathrm{ml}$. The $\mathrm{pH}$ value was adjusted to $7 \cdot 0$ and the medium autoclaved at $15 \mathrm{lb}$./sq.in. for 15 min., filtered while hot to remove precipitate, and autoclaved again at $15 \mathrm{lb}$./sq.in. for $15 \mathrm{~min}$. Liquid media were distributed in $5 \mathrm{ml}$. vol. in $6 \times \frac{3}{4}$ in. test tubes.

Commercial oleic acid was purified by distillation; $0.12 \mathrm{ml}$. $(0 \cdot 1 \mathrm{~g}$.) was dissolved in $10 \mathrm{ml} .0 .05 \mathrm{~N}$-sodium hydroxide, sterilized by Seitz filtration and diluted in PB medium to give from 3 to 100 p.p.m. as required. 
Bovine serum albumin Fraction V (Armour) was used in a concentration of $0.5 \%(w / v)$.

Activated charcoal (British Drug Houses Ltd.) was used at 0.2 and $\mathbf{0} \cdot 4 \%$ $(\mathrm{w} / \mathrm{v})$.

Solid media used were as follows:

(a) Nutrient glycerol agar prepared either with PB medium or with Wright's broth containing $1 \%(\mathrm{v} / \mathrm{v})$ glycerol but not glucose. Both Davis and Difco brands of agar were used.

(b) Albumin glycerol agar: medium (a) containing $0.5 \%(\mathrm{w} / \mathrm{v})$ albumin.

(c) Charcoal glycerol agar: medium (a) containing $0 \cdot 2 \%(\mathrm{w} / \mathrm{v})$ charcoal.

(d) Blood glycerol agar: medium $(a)$ containing $10 \%(v / v)$ citrated horse blood.

(e) Charcoal blood glycerol agar: medium $(d)$ containing $0 \cdot 2 \%(\mathrm{w} / \mathrm{v})$ charcoal.

(f) Egg-yolk glycerol agar: $\mathrm{K}_{2} \mathrm{HPO}_{4}, 2 \cdot 4$ g.; $\mathrm{KH}_{2} \mathrm{PO}_{4}, 0.6 \mathrm{~g}$.; agar 4.0 g.; glycerol, $4.0 \mathrm{ml}$; water to $300 \mathrm{ml}$. After autoclaving this solution at $15 \mathrm{lb}$./ sq.in. for $15 \mathrm{~min}$., the medium was cooled to $60^{\circ}$ and $100 \mathrm{ml}$. sterile egg yolk and $4 \mathrm{ml}$. of a $2 \%(\mathrm{w} / \mathrm{v})$ solution of malachite green were added. I am indebted to Mr Glen Buckle for this recipe.

(g) Charcoal egg-yolk glycerol agar: medium $(f)$ containing $0 \cdot 2 \%(\mathrm{w} / \mathrm{v})$ charcoal.

(h) Lowenstein-Jensen medium.

(i) Dorset egg medium.

Glassware was boiled in soapy water, scrubbed, and rinsed thoroughly with tap water, but special methods of treatment to avoid contamination with traces of fatty acids were not used. Test tubes were plugged with cotton wool and sterilized by dry heat. Before incubation the cotton wool was replaced by bark corks or rubber caps.

Organism. Mycobacterium balnei strain ' $\mathrm{X}$ ' isolated in 1950 by Linell \& Nordén (1954) from a typical human lesion was used. I am indebted to Professor Frank Fenner for a subculture. The strain produces a rough variant which was also used.

Inocula. Cultures were prepared in PB medium containing $0.5 \%(\mathrm{w} / \mathrm{v})$ serum albumin and $0 \cdot 1 \%(\mathrm{v} / \mathrm{v})$ Tween 80 and were incubated at $32^{\circ}$ for 7 days. Tenfold dilutions were made with separate $1 \mathrm{ml}$. pipettes for each dilution; the suspensions were pipetted up and down ten times each.

In the experiments illustrated by Table 1 and in experiments with solid media, $\mathbf{0} \cdot \mathbf{1} \mathrm{ml}$. of the appropriate dilution of culture was delivered into each tube of liquid medium or on to the surface of each tube of solid medium.

In the experiments illustrated by Figs. 1-3 the culture was centrifuged, washed once with PB medium and resuspended in this medium. Tenfold dilutions were made in $\mathrm{PB}$ medium except for the dilutions designed for incubation and subsequent counting; these were made in each case in the medium being tested.

Counts were made by the method of Miles \& Misra (1938) on egg-yolk agar plates incubated at $32^{\circ}$ for 9 days. Since dispersion is imperfect even in media containing Tween 80 , and clumps of bacteria as well as single organisms are 
seen on microscopic examination, Fenner, Martin \& Pierce (1949) suggested that counts of mycobacteria should refer to 'bacterial units' rather than to individual bacilli. The errors inherent in counting mycobacteria have been fully discussed by Fenner (1951). Although, in the experiments reported below, satisfactory replica counts were obtained, no corrections have been applied and the counts are therefore to be taken as approximate.

Temperatures of incubation. Culture tubes were stood upright in incubators with a range from $31^{\circ}$ to $32^{\circ}$, or from $36^{\circ}$ to $37^{\circ}$, respectively. The temperatures were recorded on thermographs.

\section{RESULTS}

Growth in liquid media at $32^{\circ}$ and at $37^{\circ}$

Preliminary experiments showed that successful cultivation of Mycobacterium balnei strain ' $\mathrm{X}$ ' in $\mathbf{P B}$ medium with or without added oleic acid depended on the size of the inoculum. Inocula too small to initiate growth in these media were frequently successful at $32^{\circ}$ and at $37^{\circ}$, when either albumin or charcoal was present (Table 1). Fig. 1 illustrates the effect of size of inoculum on growth at $32^{\circ}$ and at $37^{\circ}$ in $\mathrm{PB}$ medium to which had been added 5 p.p.m. oleic acid. With an inoculum of $c .1 .5$ million bacterial units, growth failed at both temperatures; with 3.5 million units it succeeded at $32^{\circ}$ but failed at $37^{\circ}$; with 15 million units it was successful at both temperatures. Figs. 2 and 3 show the effect on growth at $32^{\circ}$ and at $37^{\circ}$ respectively, of incorporating albumin or charcoal in the medium. An inoculum of 1.5 million units which failed to grow in the absence of these substances was successful at both temperatures in the presence of albumin or charcoal. In these experiments growth was followed by counts for a period of only $48 \mathrm{hr}$. The findings were supported by the subsequent absence or development of floccular macroscopic growth. Repeated experiments gave similar results.

\section{Growth on solid media at $32^{\circ}$}

Glycerol agar was a poor medium in that a surface inoculum of $c .1$ million bacterial units was required to initiate growth. The addition of albumin, charcoal or whole blood permitted the growth of very small inocula of the order of 10 bacterial units, but the colonies were small. On egg-yolk glycerol agar the colonies were larger although not more numerous; luxuriant growth was readily obtained and this was the best solid medium at $32^{\circ}$. Lowenstein-Jensen and Dorset egg media gave similar results.

\section{Growth on solid media at $37^{\circ}$}

On all the media tested at $37^{\circ}$ large inocula were required to initiate growth. On glycerol agar an inoculum of $c .10$ million bacterial units was necessary. Following the addition of albumin, charcoal or whole blood, growth could be obtained with $c$. 100,000 units and when charcoal was incorporated in blood agar, growth was obtained with $c$. 10,000 units. In marked contrast to its 


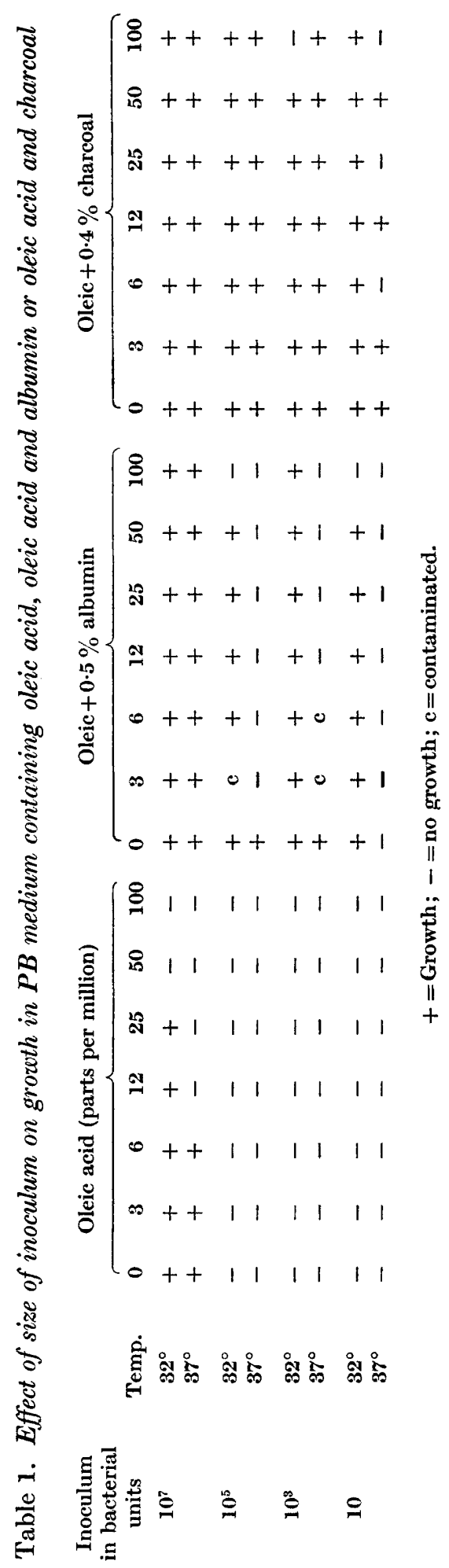


behaviour at $32^{\circ}$, egg-yolk glycerol agar was no better than glycerol agar at $37^{\circ}$ and was not improved by the addition of charcoal. Lowenstein-Jensen and Dorset media gave similar results. The omission of malachite green from the egg media did not improve them. At both $32^{\circ}$ and $37^{\circ}$, similar results were obtained with inocula developing from rough or smooth colony types.

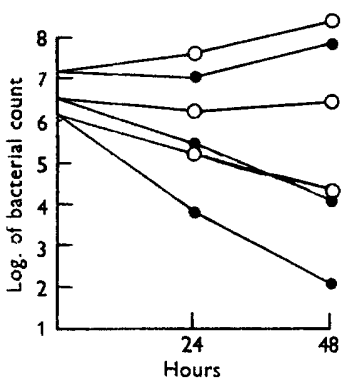

Fig. 1

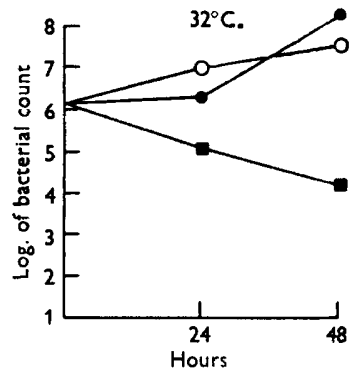

Fig. 2

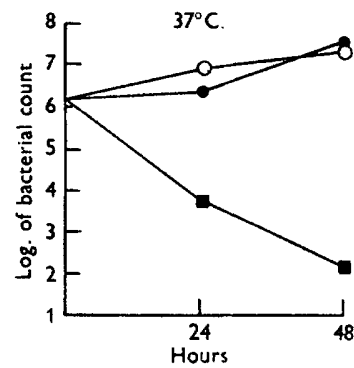

Fig. 3

Fig. 1. Effect of size of inoculum on growth in PB medium containing 5 p.p.m. of oleic acid at $32^{\circ}(\mathrm{O}-\mathrm{O})$ and $37^{\circ}(0$

Fig. 2. Effect of albumin and charcoal on growth at $32^{\circ}$. PB medium containing 5 p.p.m. of oleic acid alone ( $\square-\square)$, and with addition of $0.5 \%$ albumin $(-0)$ or of $0.4 \%$ charcoal $(\mathrm{O}-\mathrm{O})$.

Fig. 3. Effect of albumin and charcoal on growth at 37 ${ }^{\circ}$ PB medium containing 5 p.p.m. of oleic acid alone ( $\square-\square)$, and with addition of $0.5 \%$ albumin $(-0)$ or of $0.4 \%$ charcoal (O-O).

\section{Rate of growth}

In PB liquid media containing albumin or charcoal, initial growth at $37^{\circ}$ was nearly as rapid as at $32^{\circ}$ when inocula greater than a million bacterial units were used. Macroscopic growth was evident in 3-6 days but was less bulky at $37^{\circ}$ than at $32^{\circ}$. With small inocula, growth was evident after 6 days at $32^{\circ}$, but was sometimes not apparent at $37^{\circ}$ until after 3 weeks.

\section{Cultures from tissues}

Cultures were made from lung lesions in mice on the following media: PB + albumin, PB + charcoal, PB + albumin agar, PB + charcoal agar, eggyolk agar. At $32^{\circ}$ heavy growth was obtained on all media. At $37^{\circ}$ growth failed on egg-yolk agar. It was successful on all the other media, although much less abundant than at $\mathbf{3 2}^{\circ}$.

\section{DISCUSSION}

The inhibitory effect of Long's defined medium (Long \& Seibert, 1926) on the growth of Mycobacterium tuberculosis and its neutralization by serum or serum albumin was recognized by Boissevain (1940) and by Drea (1942). Boissevain (cited by Drea) found that $M$. tuberculosis was inhibited by 1 p.p.m. oleic acid. Dubos (1947) and Davis \& Dubos (1947) showed that this effect was neutralized by serum albumin. 
The inhibitory action on various organisms of a substance in agar closely resembling oleic acid has been described, and its neutralization by starch, albumin or charcoal has been demonstrated (Uyei, 1930; Drea, 1940; Ley \& Mueller, 1946; Dubos, 1947; Dubos \& Middlebrook, 1947; Glass \& Kennett, 1939; Pollock, 1947).

Davis (1948) showed that large inocula of Mycobacterium tuberculosis could metabolize and remove added oleic acid from a medium not containing albumin. Small inocula unable to grow in the medium itself produced growth in the culture filtrate in which the concentration of oleic acid had been reduced below the inhibitory level.

The observations on Mycobacterium balnei recorded above show that the inhibitory effect of oleic acid in PB medium can be neutralized by the addition of albumin or of charcoal or by the use of a large inoculum. They suggest that at least for this organism, a reduction in the temperature of incubation from $37^{\circ}$ to $32^{\circ}$ may permit growth on certain media because fatty acids in the latter are less inhibitory at $32^{\circ}$ than at $37^{\circ}$. Thus the choice of media becomes important in cultures made for diagnosis if they are to be incubated at $37^{\circ}$, particularly when the number of bacteria in a lesion is so small that they are not readily detectable in smears. The absence of growth on egg-yolk media at $37^{\circ}$ is particularly striking in contrast to the luxuriant growth obtained on these media at $32^{\circ}$. Egg yolk contains sphingomyelin, lecithin and cholesterol, all of which are capable of binding fatty acids (Dubos, 1948; Kodicek \& Worden, 1945), but it is possible that fatty acids remain available in sufficient concentration to cause inhibition of growth at the higher temperature. Reasons for the failure of charcoal to permit growth on egg-yolk agar at $37^{\circ}$ have not been investigated.

I am indebted to Mrs $\mathbf{J}$. Keir for skilled technical assistance.

\section{REFERENCES}

Boissevain, C. H. (1940). Growth promotion of the tubercle bacillus by serum albumen. Proc. Soc. exp. Biol., N.Y. 44, 110.

Davis, B. D. (1948). Absorption of bacteriostatic quantities of fatty acid from media by large inocula of tubercle bacilli. Publ. Hith Rep., Wash. 63, 455.

Davis, B. D. \& Dubos, R. J. (1947). The binding of fatty acids by serum albumin, a protective growth factor in bacteriological media. J. exp. Med. 86, 215.

Drea, W. F. (1940). The growth of human tubercle bacilli, H. 37, in synthetic medium with and without agar. J. Bact. 39, 197.

Drea, W. F. (1942). Growth of small numbers of tubercle bacilli, H. 37, in Long's liquid synthetic medium and some interfering factors. J. Bact. 44, 149.

Duвоs, R. J. (1947). The effect of lipids and serum albumin on bacterial growth. J. exp. Med. 85, 9.

Duвos, R. J. (1948). The effect of sphingomyelin on the growth of tubercle bacilli. J. exp. Med. 88, 73.

Dubos, R. J. \& Mrddlebrook, G. (194\%). Media for tubercle bacilli. Amer. Rev. Tuberc. 56, 334.

Fenner, F. (1951). The enumeration of viable tubercle bacilli by surface plate counts. Amer. Rev. Tuberc. 64, 353. 
Fenner, F., Martin, S. P. \& Pifrce, C. H. (1949). The enumeration of viable tubercle bacilli in cultures and infected tissues. Ann. N.Y. Acad. Sci. 52, 751.

Glass, V. \& Kennett, S. J. (1939). The effect of various forms of particulate carbon on the growth of the gonococcus and meningococcus. J. Path. Bact. 49, 125.

Kodrcek, E. \& Wonden, A. N. (1945). The effect of unsaturated fatty acids on Lactobacillus helveticus and other Gram-positive micro-organisms. Biochem. J. 39, 78.

Leach, R. H. \& Fenner, F. (1954). Studies of Mycobacterium ulcerans and Mycobacterium balnei. III. Growth in the semi-synthetic culture media of Dubos and drug sensitivity in vitro and in vivo. Aust. J. exp. Biol. 32, 835.

Ley, H. L. \& Mueller, J. H. (1946). On the isolation from agar of an inhibitor for Neisseria gonorrhoeae. J. Bact. 52, 453.

Linell, F. \& Nordén, A. (1954). Mycobacterium balnei. Acta tuberc. scand., Supp. 33.

Long, E. R. \& Seibert, F. B. (1926). The chemical composition of the active principle of tuberculin. 1. A non-protein medium suitable for the production of tuberculin in large quantity. Amer. Rev. Tuberc. 13, 393.

MacCallum, P., Tolhurst, J. C., Buckle, G. \& Sissons, H. A. (1948). A new mycobacterial infection in man. J. Path. Bact. 60, 93.

Mires, A. A. \& Misra, S. S. (1938). The estimation of the bactericidal power of the blood. J. Hyg., Camb. 38, 732.

Nordén, A. \& LinelL, F. (1951). A new type of pathogenic mycobacterium. Nature, Lond. 168, 826.

Pollock, M. R. (1947). The growth of H. pertussis on media without blood. Brit. J. exp. Path. 28, 295.

UYEI, N. (1930). The nature of the growth-promoting principle in the potato. Amer. Rev. Tuberc. 22, 203.

Youmans, G. P. (1946). A method for the determination of the culture cycle growth rate of virulent human type tubercle bacilli. J. Bact. 51, 703. 